\title{
THE POTENTIAL DEVELOPMENT OF COMMUNITY BASED TOURISM AT AMBENGAN VILLAGE, BULELENG REGENCY, BALI
}

\author{
Komang Trisna Pratiwi Arcana and Kadek Wiweka \\ The International Bali Institute of Tourism
}

\begin{abstract}
This study discussed the concept of sustainable tourism development which used participation-based of local communities in northern Bali, especially in Ambengan village in accordance with the concept of community-based tourism $(C B T)$. To achieve the objectives of the research, this study has identified potential Ambengan village as a community-based tourism products, which consists of; attraction, accessibilities, amenities, ancillaries, activity, and community involvement. Followed by observation method, which were analyzed by using a life-cycle model of destination, it is known that Ambengan village as a tourist destination are in phase with the attitude of the community involvement is at euphoria. However, for determining the form of community participation, this study using in-depth interviews were subsequently combined with secondary data, and then be assessed in accordance with the principles of community-based tourism (CBT). The research results indicate that this form of public participation in the management Ambengan village is at the level of participation Degree of Tokenism (informing, consultation, and placation) of goverment. Ambengan villagers have not totally get involved, and then by developing the concept of CBT, hopefully it will be able to packaging tourism products at Ambengan village with better and in accordance with the character of the village.
\end{abstract}

Keywords: Community Based Tourism; Tourism Product (6A); Destination Life Cycle; Ambengan Village

\section{Introduction}

In recent decades, the world tourism has grown significantly. UNWTO (2014) noted that in 2013, the growth of international tourists has reached 1,087 million tourists, with total revenues of US $\$ 1,159$ billion. It certainly will increase the acceptance of income, employment opportunities, and several positive impacts. However, Goeldner and Ritchie (2009) argue that in addition to a positive impact, tourism can also have a negative impact. So it can be analogized as a coin that has two different sides.

In addition to the quantity of development, a good number of tourists and the growth of revenue receipts, tourist behavior trend are generally also experienced a shift. Leksakundilok (2004) noted that the phenomenon of tourism 
has shifted from conventional forms, which are characterized by the development of mass tourism developed towards modern. However, these phenomena at the present had been developed again. Saturation and desire of tourists encourage the emergence of an era of alternative tourism. This form of tourism is a kind of response of tourist awareness of the sustainability, both in terms of environmental, economic, social, and cultural. So that, it creates various types of new tourism products that has the principle of sustainability values such as indigenous tourism, pro-poor tourism, ecotourism, adventure tourism, educational tourism, to community-based tourism (Guzmán et al., 2011).

In the Asia, a sustainable tourism, especially on the development of local communities has become a crucial issue in the tourism destinations that are 'growing' (Haya, 2008). The concerns about the balance between the benefits and the impact tourism have been in the spotlight for tourism actors, policy makers, professionals, NGO (non government organization), and researchers. One of the tourist destinations that are categorized as in developing stage is Bali. Based on data from the year 2013 on the distribution of tourists visit the town or district in Bali, discovered an interesting fact that most or $75 \%(8,183,299)$ tourists just spread on the southern Bali region (Tabanan, Gianyar, Denpasar and Badung). This uneven distribution of tourists certainly raises concerns about the effect of tourism (impacts and benefits) in some regions.

The tourism in southern Bali which is developing rapidly and tend uncontrolled, open up an opportunities for other regions to develop their potential as an alternative and more planned destinations. One of the destinations in northern Bali which have tourism potential both natural and cultural is Ambengan village. Ambengan village is one of the villages in Buleleng precisely in the District Sukasada. Ambengan village is located on the green hill, about $6 \mathrm{~km}$ south of the city of Singaraja. As some traditional village in Bali, Ambengan village also has traditional art and culture that are still maintained until today

With its potential resources, Ambengan village should have a concept of tourism product development in accordance with the characteristics of the local area. Tourism development is expected to have a positive impact for the local community, both economically, socio-cultural, and even be able to conserve natural owned. One concept that is being developed is Community-Based Tourism (CBT). Many countries have introduced this concept as a strategy of development in rural areas, which have the characteristics of a traditional agrarian industry. CBT is also one type of sustainable tourism that is concerned with the welfare of local communities (Gabito, 2013; Okazaki 2008).

CBT is a concept that focused on active participation of local communities in tourism activities and share profits from those activities (Guzmán et al., 2011; Suriya, 2010). Johnson (2010) adds, specifically the concept aims to improve the economic, social and cultural rights of local communities. However, Okazaki (2008) stated that although many studies have revealed the benefits and importance of $\mathrm{PMB}$, but the constraints that generally arises is about how to identify the shape and level of participation of local communities from the planning, implementation and management of tourism as an industry.

Based on this background, the study of the development of the tourism product in accordance with the characteristics of potential Ambengan village needs to be done. Especially through the development of PMB products which 
aim to increase the participation of local communities, so that the benefits of tourism activities can be felt directly and optimally. In general, this study aims to assess the form of participation of local people in the village Ambengan accordance with CBT. While specifically, the study will identify the potential at the Village Ambengan that can be packaged as a community-based tourism product, based on the elements of attractions, accessibilities, amenities, ancillary, activity, package available and community involvement. Furthermore, this study also determines the position of the potential of the Ambengan village in accordance with the development model of tourism products (destination lifecycle).

\section{Literature Review}

In supporting this research, some literatures of which are considered relevant literature is used as a reference and consideration in the research process. Research on community-based tourism product development is one of the study conducted by Nurhidayati (2007) entitled "Community Based Tourism (CBT) sebagai Pendekatan Pembangunan Pariwisata Berkelanjutan". That research states that one of the approaches that can be done to emphasize the involvement of local people (directly and indirectly) in managing a sustainable tourism destination is Community Based Tourism (CBT).

A second study conducted by Astuti (2010) with the titled "Pemetaan Dampak Ekonomi Pariwisata Dalam Penerapan Konsep Community Based Tourism (CBT) Studi Kasus Desa Wisata Kebon Agung di Kabupaten Bantul". This study aims to identify and analyze the economic benefits created by the application of the concept of CBT. The study states that there are some limitations in the application of the concept of CBT in Kebon Agung village, among others leakage, the weakness of the local management and bargaining power, limited carrying capacity and the lack of availability of land agricultural practices. In addition the concept of the development of Community Based Tourism (CBT) which is applied in the village of Kebon Agung, a real benefit to the community in the form of additional revenue.

The third study entitled "Pengembangan Wisata Berbasis Masyarakat (Community Based Tourism/CBT) di Desa Taman Nasional Gunung Halimun Salak" conducted by Sulistiani, Pribitari, and Apriliani (2011). The study's results showed that the development of community-based tourism can be done through two strategies: the first by designing tourist products and the second, by increasing the ability, skill and competence of the community in managing tourism destinations. Some of these studies contribute both as an input and consideration in this study.

\section{Methodology}

Field data collection is using three techniques, such as in-depth interviews, observation, and inspection documents. Depth interview begins with determine 
the number of informants by using purposive sampling and snow ball sampling that consider to their competence in accordance with the needs of the data (Ratna, 2010). The observation is done by using non-participant observation, where the researcher was not involved and only became independent observers of community activity in Ambengan village. By using this technique, it is expected to get the actual data of the characteristic of the Ambengan villange such as the state of the attractions, facilities, access roads and aktivitas. Further, the design of this study is a qualitative approach, in which data analysis method is descriptive qualitative method. The use of this method aims to make a description or picture of a systematic and objective, on the facts, nature, characteristics and relationships between elements of the existing or a particular phenomenon (Kaelan. 2005).

\section{Results and Discussion}

\section{Ambengan Village Potential as Community-Based Tourism Product}

\section{Natural Attraction}

Attractions or tourist attraction could consist of a combination of natural resources, cultural resources and man-made attraction. In the village of Ambengan, the main tourist attraction is nature and culture. In general, the village of Ambengan has unique characteristics and abundant natural resources. This is because the location is surrounded by the government conservation forest and is limited by the river with 12 waterfalls. These stretches from conservation forest area owned by the government until the village boundary. They are Puncak Sari Waterfall, Aling-aling Waterfall, Kroya Waterfall, Tibuan Kembar Waterfalls, Pucuk Waterfall, and Telabah Lawas Waterfall. While three other waterfalls that have not named yet are located behind the Puncak Sari Waterfalls and the other two are in Kacut region near to the boundary between the Ambengan village, Sangket Village and Village Sambangan. Besides the waterfall, this village also own beautiful rice terrace that can be found in most areas of Ambengan village.

\section{Cultural Attraction}

Ambengan village has the potential of art and culture that has become a part of the local community. The appeal of culture in the form of artistic activities are organized in any ceremonial activities such as dances, art of percussion and several crafts that now become the livelihood of local residents. At the other hands, art is not only used as a cultural heritage, but also a tourist attraction for tourists or commodity, such as: Keraras craft, basket craft, Joged Werdhi Budaya

dance, Bukit Temple and the Penarungan Hill; Dutch Pal area of approximately 10 acres, where the venue can be used to point of view, and Pesantihan.

\section{Accessibilities}

In general, accessibility is one element that connects among the tourists, the tourist attractions and other tourism facilities. Preferably, a tourist destination is offering non-physical aspects of convenience for tourists, such as the ease of outreach information and regulation. According to the location, Ambengan village lies in the strategic area, because it is on transportation lines which are easy reach. But to go straight to Jembong waterfall, taxis or private vehicles are needed, 
because of the distance is about $5 \mathrm{~km}$ from the village entrance. However, the distance between the Ambengan village and the nearby cities are within easy reach including city of district and regency.

The transportion facilities in the area are sufficient to public transportation routes serving Denpasar - Singaraja as a liaison. To reach this place from Singaraja City is only 5 minutes, whereas from Denpasar City takes about 2 hours. However, the accessibility to natural attraction is not in a good condition at the moment. It requires a rapid action from the government since it is one of the important elemen within a destination. On the other hands, Ambengan village has the disadvantage also in terms of ease (accessibilities) non-physical, such as information. This is because the tourists still encounter difficulties in getting information about tourist attractions (waterfalls and rice terraces) in the village.

\section{Amenities}

Amenities or tourism support facilities is an element that consists of a multi-sector approach. Just like other elements, support facilities are also affected and affect other sectors. This element has an important role in supporting major tourism potential possessed by a tourist destination. General support facilities that can be used for tourism activities in the Ambengan village, including; stalls, traditional market, taxi rank located at the entrance of the village and also a bus terminal which Sangket terminal located in Sukasada district, that is about $4 \mathrm{~km}$.

Several constraints of the facility are the lack of parking area (only for motorcycle) and a less optimal service of information center for tourism activities arround the waterfall. Similarly, the public toilet facilities are limited. As for tourists who want to spend the night or stay in the Ambengan village, local communities provide accommodation by using a private home which is managed according to their habits and are not intended specifically for business tourism.

\section{Ancillary services}

Some tourist destinations provide additional service centers, both in public and private organizations (non-government). In the local scope, the organization generally has a function in marketing a destination, carring out the coordination and supervising the construction of tourist destinations, and coordinating with various bussiness stakeholders. However, in Ambengan village, partly managed by the Kelompok Sadar Wisata Banten Sari (tourism awareness group), in Ambengan village and is directly under supervision of Korwil (regional coordinators) Jembong. There are some multiple stakeholders (tourism players) involved; both in the planning, managing and monitoring of them are, such as: Ambengan village government, Ambengan indigenous village, Badan Permusyawaratan Desa (BPD), Lembaga Pemberdayaan Masyarakat (LPM) or Institute for Community Empowerment, Kelompok Tani or farmer cooperatives, Kelompok Sadar Wisara or tourism awareness group, and Sekaa Subak (community of irigation system).

\section{Activities}

Besides providing the tourism supporting infrastructure, a destination also needs to develop different types of activities that can be carried by tourists during 
visits. This meant that the tourists directly involved in tourist attractions. Some of the activities that may be carried by tourists in the various tourist attaction in Ambengan village, including: Sight-seeing, photography, recreation, cycling, hiking, meditation, tracking, swimming, and free jumping.

\section{Available packages}

One role of travel agents (intermediaries' elements) is to package and market their tourism products to tourists. But in its development, a destination can not simply rely on the connecting that element. The fact that appeals in Ambengan village has not been packaged specifically so that it is not known by tourists. Until today, the Ambengan Village still relies on tourism promotion activities undertaken by local governments. This is certainly a weakness from the standpoint of promotion.

\section{Community involvement}

The issue of community involvement or tourism community is getting attention (Madiun, 2012) it is primarily related to tourism development towards a sustainable tourism. The involvement can help guide the development of tourism in accordance with the needs of local communities and local wisdom. In simple terms, it can be said that the local community is in a position which is very important in determining the direction of development of tourism in the region.

Rural communities in Ambengan are not currently fully-engaged in planning and managing the development of a tourist attraction. But the local society has been involved as part of the tourism industry which began to develop in their area. Some jobs related to tourism are souvenirs maker, guide, and tour planner. Furthermore, some people also have stalls or warung makan that can cater to tourists who want to enjoy Ambengan village tradisional food. However, this phenomenon illustrates that the majority of local people are only involved in low-level managerial. It is certainly not in line with the concept of communitybased tourism destination.

\section{The Position of Ambengan Village Potential based on analysis of Destination Life Cycle}

Based on the analysis of the development model of tourism products (destination life cycle), Ambengan village are in involvement phase. In the phase of involvement, tourist arrivals began to increase. Increasing in this tourist visits, encourages local residents to offer tourist facilities exclusively to visitors. Because of the increasing of interest to interact with the community, promotion of tourist destinations also started to be initiated though it has not been perfect yet.

Some evidences suggest that the potential of tourism products in Ambengan village primarily on its natural attractions is not been managed optimally. Ambengan village is a village that rich with natural attractions, so the Buleleng government has also been set as Ecotourism (Department of Culture and Tourism Buleleng, 2009: 15). Ecotourism is managed by Kelompok Sadar Wisata (Pokdarwis) Banten Sari led by Putu Sunada. Awareness of the potential of nature that can be managed to get their portion of the tourism pie has been formed since 2008. The tourism infrastructure such as paved roads, bridges, direction, and telecommunications systems have been built quite well. Some unmaintened 
tourism infrastructure can still be found there. The development of this tourism infrastructure is a form of awareness of the potential of tourism in Buleleng. It is not only from Ambengan villagers, but the government of Buleleng district, up to Bali Province for assisting the development of the tourism product. However, the workshop for the managers of ecotourism is not running consistently. So that it could be said that the human resources of Ambengan village is unable to manage tourism products (observations, 2015).

Levy dues into the natural attractions are still managed by the villagers who live around the attractions for about $\mathrm{Rp} 5.000$ each person. The community also provides a local tour guide, but there is no clear information about where the tourists can see the guide. Lack of information and also non- integrated natural destination product management is occurred in this tourist destination. Knowledge and skill in managing tourist destinations have not owned by the majority of the villagers who at the first livelihood as farmers and farm village. Ambengan villagers expect that the government has to develope the tourism potential seriously through one of which improvement the quality of human resources. The most basic things that they need are the ability in a foreign language (Interview result with Made Raksawan, Secretary of Kelompok Sadar Wisata on September 19, 2015). Ambengan community realizes that having foreign language skills will enable them to communicate with foreign tourists.

The increasing of interaction with local and foreign tourists caused a significant effect on the desire of rural communities to manage a tourist destination professionally. However, there is still lack of management knowledge, and also there is no expertise in the field of tourism. For the time being, Kelompok Sadar Wisata only works on limited areas to maintain the cleanliness of the village and improve security when receiving tourist visits. The potential of Ambengan village which began to be known by tourists both domestic and foreign tourists are increasing the public desire to manage tourism destination independently and professionally. It is characterized by the formation of group awareness Banten Sari and explores the potential of local efforts such as selling handicrafts from bamboo on tourists who come to visit the tourist attractions of the natural waterfall. Meanwhile, the government and the Province of Bali, Buleleng regency until now still give physical assistance such as improving the accessibility to the attractions. It is not accompanied by consolidation of knowledge and expertise in managing the villagers Ambengan tourist destinations. The implication is ecotourism products have not contributed the maximum impact yet. Society has the potential to manage tourism products independently, and hopefully they can immediately feel the benefits.

\section{Participation of Local Communities in Ambengan village according to the concept of Community Based Tourism}

Ambengan village has tourism potential that utilize natural resources as the main attractions. Becoming ecotourism has been established to Ambengan village in order to develop their potential as revenues from tourism. Develop the concept of Community Based Tourism in the management of tourism products there, will be an effort to involve local communities in the management completely. The assessment of socio-economic and demographic Ambengan villagers was divided into 6 categories of gender, marital status, age society, educational background, 
employment, and income. This information is used to improve the empirical understanding of the characteristics of the village community. Based on these data, it is known that the diversity of public characteristics and the tourism sector become another livehood beside as farmers. Income level increased as same as people who work on cruise ships. However, working in the tourism sector by developing Ambengan village itself was still low and not very attractive.

The participation of local communities in running their CBT with dimensional concept in it during the implementation is not only begun when the process of planning, implementation of the concept, but also at the time of the evaluation of implementation. The results showed that although the Ambengan village is one of the ecoturism products in Bali, but has not been well-managed (the interview with Made Raksawan on August 25, 2015). The socialisation about the potential development of the village into one of the products Ecotourism is work well at first. Many stakeholders are involved such as local government, academia, and other tourism industry players. However, the event does not take place consistently. It caused in decreasing quality of service, and the Ambengan villagers even has lack of understanding of how to package tourism products become more attractive, in addition to merely maintain the cleanliness and safety of the village. Community involvement during planning stage only supports the programs that offered by the government. They have not been able to design independently how development programs that proper to the characteristics of the village.

Every decision will be made by the government in this case limited to development and improvement of infrastructure (public toilets, parking areas, and the improvement of the road) is always socialized with the villagers at first. Ambengan villagers take a part in decision-making, even less so a proposal for the construction of supporting infrastructure proposed by the communities themselves. Although, during its implementation spent a long time (interviews with Made Raksawan on August 25, 2015). Practically, tourism activities in Ambengan village still become a side activity besides the main livelihood of rural communities as farmers and ranchers. The youths in the village Ambengan prefer to seek a job in the big cities rather than the developing tourism sector. As stated by the head of Ambengan village, Made Putrawa (interviews on September 1, 2015) that the biggest obstacle in the development of the tourism sector is the quality of human resources, especially the ability to communicate with a foreign language and use technology to promote the destination. It needs a gradual training or improvement of their human resources quality for the tourist destinations management, so that they can implementate the skill independently.

Respon of community to the development of tourism sector in Ambengan village are in a phase of euphoria where they receive arrival tourists with good and open. Community involvement in the management of community-based tourism destination according to Arnstein theory can be classified into the Degree of Tokenism participation rate or accept some provisions which set includes the provision of information, consultation, and referral of the authority in this case is the government. Some actors who play a role in decision-making is the village chief of Ambengan, Chairman of POKDARWIS, and the approval and support from Ambengan villagers. So, it can be concluded that the public has not totally involved from planning, implementation, as well as an evaluation of the 
management of tourism products owned. Reviewing of tourism potential and enthusiasm the people are quite positive, the product development of ecotourism in Ambengan village can refer to the concept of Community-Based Tourism so that people can feel the impact or the positive benefits of the tourism sector directly without the intervention of investors to maintain the character of the village itself and foster entrepreneurship in the future.

\section{References}

Anonim. (2009). "Database Atraksi Wisata di Kabupaten Buleleng”. Buleleng: Dinas Kebudayaan dan Pariwisata Kabupaten Buleleng.

Anom, I Putu. (2010). "Pembangunan Pariwisata Berkelanjutan”. Pariwisata Berkelanjutan Dalam Pusaran Krisis Global. 1(1):1-14.

Anonim. (2012). Perda provinsi Bali Nomor 2 Tahun 2012 Tentang Tujuan Pembangunan Pariwisata Bali.

Anonim. (2014). Data Kunjungan Wisatawan Mancanegara ke Indonesia Berdasarkan Pintu Masuk. (http://www.budpar.go.id/informasi/2014, diakses Pada Tanggal 5 Februari 2015).

Anonim. (2014). “UNWTO 2014". Tourism Highlights 2014 Edition.

Anonim. (2015). "Data Kunjungan Wisatawan Pada Kota Atau Kabupaten Di Bali”. (http://www.disparda.baliprov.go.id/informasi/2013, diakses Pada Tanggal 5 Januari 2015).

Arcana, Komang Trisna Pratiwi. (2014). "The Implementation of Sustainable Event Management Concept Into MICE Management At Nusa Dua Resort, Bali'. Thesis. Postgraduate Studies, Udayana University, Denpasar.

Arnstein, Sherry R. (1969). "A Ladder Of Citizen Participation". (http://www.google.com, diakses pada tanggal 11 Mei 2015).

Astuti, Yuniati Dina. (2010). "Pemetaan Dampak Ekonomi Pariwisata Dalam Penerapan Konsep Community Based Tourism (CBT) Studi Kasus Desa Wisata Kebon Agung di Kabupaten Bantul'. Skripsi. Surakarta: Universitas Sebelas Maret.

Cooper, Chris. et.al. (1993). "Tourism Principles and Practice". England:

Doswell, Roger. (2002). "Tourism, How Effective Management Makes The

Gabito, Olivette A. (2013). "Growing Rural Employment Through CommunityBased Touris" m. 12th National Convention on Statistics (NCS), EDSA Shangri-La Hotel, Mandaluyong City.

Goeldner, Charles R., and J.R. Brent Ritchie. (2009). "Tourism Principles, Practice, and Philosophies". Eleventh Edition. New Jersey: John Wiley \& Sons, Inc.

Guzmán et al. (2011). "Community - Based Tourism In Developing Countries: A Case Study. Tourismos: An International Multidisciplinary Journal Of Tourism". Volume 6, Number 1. University of Córdoba, Víctor PavónUniversity of Córdoba.

Haya, Calle Capitan. (2008). "Tourism and Community Development, Asian Practices". 2008 World Tourism Organization, 42, 28020 Madrid, Spain. 
Johnson, Peter A. (2010). "Realizing Rural Community Based Tourism Development: Prospects for Social-Economy Enterprises. Journal of Rural and Community Development, Journal of Rural and Community Development". McGill University, Montreal, Quebec, Canada.

Kaelan. (2005). "Metode Penelitian Kualitatif Bidang Filsafat - Paradigma bagi Pengembangan Penelitian Interdisipliner Bidang Filsafat, Budaya, Sosial, Semiotika, Sastra, Hukum dan Seni”. Yogyakarta: Paradigma.

Kusmayadi. dan Sugiarto, Endar. (2000). "Metodologi Penelitian dalam Bidang Kepariwisataan". Jakarta: PT. Gramedia Pustaka Utama.

Leksakundilok, Anucha. (2004). "Community Participation In Ecotourism Development In Thailand". Thesis. Australia: University Of Sidney.

Mason, Peter. (2003). "Tourism Impacts, Planning and Management”. Oxford: Butterworth - Heinemann.

Nurhidayati, Sri Endah. (2007). "Community Based Tourism (CBT) Sebagai Pendekatan Pembangunan Pariwisata Berkelanjutan". Jurnal Masyarakat, Kebudayaan, dan Politik, Th. XX., No.3, Juli - September 2007, 191 - 202. Surabaya: Universitas Airlangga.

Okazaki, Etsuko. (2008). “A Community-Based Tourism Model: Its Conception And Use". Journal Of Sustainable Tourism, Vol. 16, No. 5. University, Japan. Taylor \& Francis.

Pitana, I Gde, dan I Ketut Surya Diarta. (2009). "Pengantar Ilmu Pariwisata". Yogyakarta: C.V. ANDI OFFSET.

Pujaastawa, I.B.G. (2004). "Pariwisata Terpadu Alternatif Model Pengembangan Pariwisata Bali Tengah". Badung: Universitas Udayana, Bali.

Prasiasa, Dewa Putu Oka. (2013). "Destinasi Pariwisata Berbasis Masyarakat". Jakarta: Salemba Humanika.

Ratna, N. K. (2010). "Metodologi Penelitian Kajian Budaya dan Ilmu Sosial Humaniora pada Umumnya”. Yogyakarta: Pustaka Pelajar.

Rorah, Dhanik Nor Palupi. (2012). "Pengelolaan Pariwisata Berbasis Masyarakat (Community Based Tourism) Di Desa Wisata Kebon Agung, Kecamatan Imogiri'. Skripsi. Universitas Negeri Yogyakarta.

Sastrayuda, Gumelar S. (2010). "Konsep Pemberdayaan Masyarakat Berbasis Pariwisata (Community Based Tourism)". Hand Out. (www.google.com, diakses pada tanggal 14 Januari 2014).

Sugiyono. (2007). "Metode Penelitian Pendidikan (Pendekatan Kuantitatif, Kualitatif, dan $R \& D$ ”. Cetakan Ketiga. Bandung: Alfabeta.

Sulistiani, Siti Nurika., Lighar Dwinda Prisbitari, dan Kenny Apriliani. (2011). "Pengembangan Wisata Berbasis Masyarakat (Community Based Tourism/ CBT) Di Desa Malasari, Taman Nasional Gunung Halimun Salak”. PKM Artikel Ilmiah. Bogor: Institut Pertanian Bogor.

Suriya, Komsan. (2010). "Impact of Community-based Tourism in a Village Economy in Thailand: An Analysis with VCGE Model". (www.researchgate.net, diakses pada tanggal 10 April 2015).

Suryawardani, I. G. A. Oka. (2014). "Tourism Leakage From The Accommodation in Bali'. Dissertation Summary. Postgraduate Studies, Udayana University, Denpasar.

Tribe, John. (2009). "Aspects of Tourism, Philosophical Issues In Tourism". UK: 
Ward, Louise Twining. (2004). "A Toolkit for Monitoring And Managing Community-Based Tourism". (www.snvworld.org, diakses pada tanggal 18 Agustus 2014).

Weaver, David. dan Laura Lawton. (2006). “Tourism Management”. Edisi Ketiga. Australia: John Wiley \& Sons Australia, Ltd. 